\title{
The effect of heat treatment on the nutritive value of milk for the young calf
}

3*. The effect of the preheating treatment of spray-dried skim milk and a study of the effect of ultra-high-temperature treatment of separated milk

\author{
By K. W. G. SHILLAM† AND J. H. B. ROY \\ National Institute for Research in Dairying, Shinfield, Reading \\ AND P. L. INGRAM \\ Royal Veterinary College, Camden Town, London, N.W. I \\ (Received I4 February 1962)
}

In an earlier experiment, Shillam, Roy \& Ingram (1962) observed a high incidence of mortality, associated with an Escherichia coli localized intestinal infection, in colostrum-fed calves given a diet containing a skim milk dried by the Gray-Jensen process. It appeared that about $50 \%$ of the whey proteins of the liquid milk had been denatured during the drying process, presumably as a result of preheating the milk at a temperature of $74^{\circ}$ for about $30 \mathrm{~min}$. The experiment reported now compares the nutritive value of this milk for the calf with that of a spray-dried skim milk that had been preheated before drying at a temperature of $77^{\circ}$ for ${ }_{1} 5 \mathrm{sec}$ only. The opportunity was also taken to find the effect, on the performance of the calf, of milk that had been subjected to a temperature of $135^{\circ}$ for $\mathrm{I}-3 \mathrm{sec}$ (ultra-high-temperature (UHT)treated milk). It has originally been noted by $R$. Aschaffenburg (1956, private communication) and later reported by Shillam, Dawson \& Roy (1960) that the UHT process caused considerable denaturation of the whey proteins of milk, and it was thus considered that the performance of calves given this milk might be no better than that of calves given the dried milk prepared by the Gray-Jensen method. For ease of presentation, the skim milk preheated more severely at $74^{\circ}$ for $30 \mathrm{~min}$ (GrayJensen method) will be referred to as milk $A$ and the skim milk given the milder preheating treatment at $77^{\circ}$ for $I_{5} \mathrm{sec}$ as milk $\mathrm{B}$.

\section{METHODS}

\section{Plan of experiment}

The experiment was made during the winter of $195^{6-7}$. Thirty-four Ayrshire and thirty-three Shorthorn bull calves in a randomized block design were used. Eight blocks consisted of Ayrshires, eight of Shorthorns and the last block of both Ayrshires and Shorthorns. The plan of the experiment was as shown on p. 586. Treatment I 5 was omitted from the last block of the experiment; a calf was allotted to this treatment

* Paper no. 2: Brit. F. Nutr. (1962), 16, 267.

$\uparrow$ Present address: Huntingdon Research Centre, Huntingdon. 
but it was later found that it had suckled its dam before collection. This calf was rejected from the experiment and could not be replaced as the calving season had finished. Management of the calves throughout the experiment was as described earlier (Shillam et al. 1962).

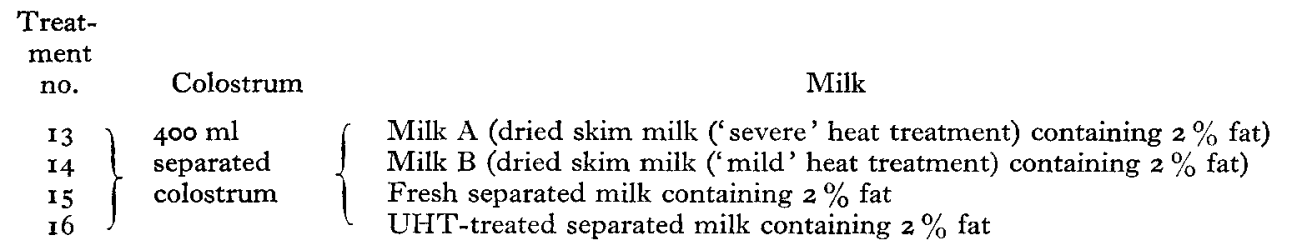

\section{Diets}

Colostrum. Colostrum was separated and stored in the usual manner (Shillam et al. r962); each calf was given $400 \mathrm{ml}$ as its first meal.

Milk. The diet of the first ten calves on treatment 15 contained bulked separated milk from the Institute's Church Farm herd, and that of the last six calves bulked separated milk from the Arborfield Hall Farm herd, and was prepared as described earlier (Shillam et al. I962). The change was made because it was found that one cow in the Church Farm herd was giving milk containg high numbers of coliform organisms, and it was considered that this milk might be having an adverse effect on the performance of the calves on this treatment. The skim-milk powders A and B were reconstituted at the rate of $\mathrm{I} \mathrm{lb}$ milk powder $/ 9 \mathrm{lb}$ water, and $\mathrm{I} \mathrm{lb}$ of a milk containing $20 \%$ margarine fat (Shillam et al. 1962) was added to each $9 \mathrm{lb}$ of milk. UHT-treated separated milk was prepared in 60 gal batches by heating at a temperature of $\mathrm{I} 35^{\circ}$ for $\mathrm{I}-3 \mathrm{sec}$ as described by Shillam et al. (1960); I lb of the milk of $20 \%$ fat content was added to each $9 \mathrm{lb}$ of UHT-treated separated milk given to calves on treatment $\mathrm{I} 6$. The daily allowance of milk was $\mathrm{I} / \mathrm{lb} / \mathrm{I}$ o lb live weight except when scouring occurred (Shillam et al. 1962). In addition, each calf was give daily a supplement of 3500 i.u. vitamin $A$ in the form of halibut-liver oil concentrate and 700 i.u. synthetic vitamin $D_{3}$, dissolved in arachis oil.

\section{Analytical methods}

The partition of nitrogen was determined on one sample of each of the milk powders A and B by the method of Aschaffenburg \& Drewry (1959).

\section{RESULTS}

\section{Mortality}

The results are given in Table $\mathrm{r}$. Four of the seventeen calves given milk B died compared with nine of seventeen given milk A. Although the difference was not very marked, calves given milk $A$ tended to succumb at an earlier age than those given milk B. Nine of the seventeen calves given the diet containing UHT-treated separated milk died, compared with nine of sixteen given the fresh separated-milk diet. Four of the first five calves given the fresh separated-milk diet survived, but the next five 


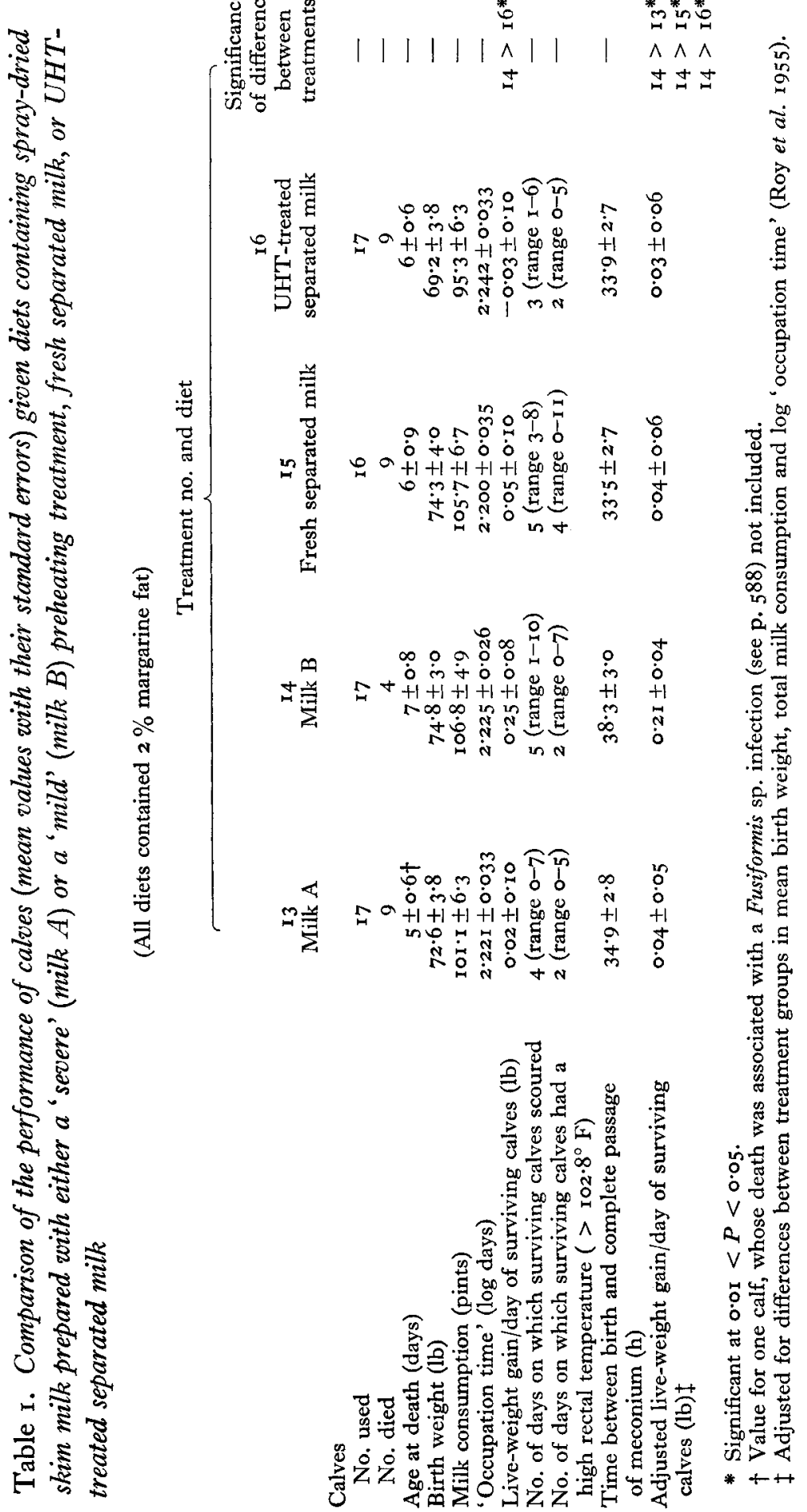


calves on this treatment died. Of the remaining six calves on this treatment, all of which were given fresh separated milk from the Arborfield Hall Farm herd, three died.

\section{Autopsy findings}

Table 2 shows the post-mortem findings on the calves that died. Of the thirty-one deaths, thirty were associated with an $E$. coli infection. Twenty-nine of the deaths were associated with an $E$. coli localized intestinal infection and one with an $E$. coli septicaemia. The death of the remaining calf (at 20 days of age) was associated with a Fusiformis sp. infection (calf diphtheria).

Table 2. Number of calves that died, classified according to post-mortem findings

\begin{tabular}{|c|c|c|c|c|c|}
\hline \multirow{2}{*}{\multicolumn{2}{|c|}{ Post-mortem finding }} & \multicolumn{4}{|c|}{ Treatment no. and diet } \\
\hline & & $\stackrel{\text { I3 }}{\text { Milk A }}$ & $\begin{array}{c}14 \\
\text { Milk B }\end{array}$ & $\begin{array}{c}\text { I5 } \\
\text { Fresh } \\
\text { separated } \\
\text { milk }\end{array}$ & $\begin{array}{c}\text { I6 } \\
\text { UHT-treated } \\
\text { separated } \\
\text { milk }\end{array}$ \\
\hline & $\begin{array}{l}\text { Localized intestinal } \\
\text { infection }\end{array}$ & 8 & 4 & 8 & 9 \\
\hline Escherichia coli & $\begin{array}{l}\text { Septicaemia and } \\
\text { polyserositis }\end{array}$ & - & 一 & $\mathbf{I}$ & - \\
\hline Fusiformis sp. & Calf diphtheria & I & - & - & - \\
\hline
\end{tabular}

Milks A and B, spray-dried skim milk prepared with a 'severe' (A) or 'mild' (B) preheating treatment. All diets contained $2 \%$ margarine fat.

\section{Performance of the surviving calves}

Table I shows that the observed live-weight gain of surviving calves given a diet containing milk B was significantly greater than that of calves given a diet containing UHT-treated separated milk and greater, but not quite significantly so, than that of calves given diets containing milk A or fresh separated milk. After adjustment of the mean daily weight gains for differences between treatment groups in mean birth weight, total milk consumption and log 'occupation time' (see Roy, Palmer, Shillam, Ingram $\&$ Wood, 1955), the difference in growth rate between calves given milk B and those given any of the other three milk diets was significant. The relative partial regression coefficients with their standard errors are given below; the adjusted mean values are given in Table I.



The mean live-weight gain of surviving calves given the fresh separated-milk diet was lower than that normally expected, and the incidence of scouring and of a high 
rectal temperature tended to be higher than that of calves on the other treatments. This lowered performance may have been due to the high coliform content of the separated milk from the Church Farm herd; the mean daily change in live weight of the surviving four calves given the diet containing fresh separated milk from the Church Farm herd was $-0.16 \mathrm{lb}$ compared with $+0.30 \mathrm{lb}$ for the three surviving calves given fresh separated milk of a lower coliform content from the Arborfield Hall Farm herd. However, the mean daily weight gain of calves given milk B was $+0.08 \mathrm{lb}$ during the period that the separated milk was obtained from Church Farm and $+0.26 \mathrm{lb}$ during the period that the source was Arborfield Hall Farm, which suggests that the coliform content of the separated milk was not responsible for the adverse performance of the first ten calves given this diet. Moreover, subsequent experiments in which milk containing $5^{-8} \times 10^{5} \mathrm{E}$. coli $/ \mathrm{ml}$ has been given to calves have shown little detrimental effect of the coliform organisms even when they were of a specific serological type associated with an $E$. coli localized intestinal infection (Roy \& Shillam, I960).

Calves given milk $B$ tended to pass their meconium at a slower rate than calves on the other three treatments.

Table 3. Nitrogen partition of the spray-dried skim milks

\begin{tabular}{|c|c|c|c|c|}
\hline & \multicolumn{2}{|c|}{$\begin{array}{c}\text { Milk A* } \\
\text { ('severe'preheating } \\
\text { treatment) }\end{array}$} & \multicolumn{2}{|c|}{$\begin{array}{c}\text { Milk B* } \\
\text { ('mild' preheating } \\
\text { treatment) }\end{array}$} \\
\hline & $\begin{array}{l}\mathrm{mg} / \mathrm{IOO} \mathrm{g} \\
\text { milk }\end{array}$ & $\begin{array}{c}\text { As a } \% \\
\text { of total } \mathrm{N}\end{array}$ & $\underset{\text { milk }}{\mathrm{mg} / \mathrm{roog}}$ & $\begin{array}{c}\text { As a } \% \\
\text { of total } \mathrm{N}\end{array}$ \\
\hline Total N & 573 & 100.0 & 559 & $100 \cdot 0$ \\
\hline Casein $\mathrm{N} \dagger$ & 487 & $85 \cdot 0$ & 436 & $78 \cdot 0$ \\
\hline Non-casein $N$ & 86 & I 5.0 & 123 & $22 \cdot 0$ \\
\hline Non-casein protein $\mathbf{N}$ & 48 & $8 \cdot 4$ & 86 & $15 \cdot 4$ \\
\hline Total albumin $\mathrm{N}$ & 28 & $4 \cdot 9$ & 62 & II $\cdot \mathbf{I}$ \\
\hline$\beta$-Lactoglobulin $\mathrm{N}$ & 20 & $3 \cdot 5$ & 39 & $7 \cdot 0$ \\
\hline Residual albumin $\mathrm{N} \ddagger$ & 8 & $\mathrm{I} \cdot 4$ & 23 & $4 \cdot 1$ \\
\hline Proteose-peptone + globulin $\mathrm{N}$ & 20 & $3 \cdot 5$ & 24 & $4 \cdot 3$ \\
\hline Non-protein $\mathbf{N}$ & $3^{8}$ & $6 \cdot 6$ & 37 & $6 \cdot 6$ \\
\hline
\end{tabular}

\section{Nitrogen partition of the dried skim milks}

The partition of nitrogen in each of the reconstituted dried skim milks is given in Table 3. Although the amounts of total $\mathrm{N}$ in both milks were similar, the non-casein protein $\mathrm{N}$ in milk $\mathrm{A}$ was only $56 \%$ of that in milk $\mathrm{B}$. Of the albumin $\mathrm{N}$, which was the fraction of the non-casein protein $\mathrm{N}$ showing the largest difference, milk A contained only $50 \%$ of the $\beta$-lactoglobulin $\mathrm{N}$ and $35 \%$ of the residual albumin $\mathrm{N}$ present in milk B. 


\section{DISCUSSION}

As judged by the number of calves that died and by the live-weight gains of those that lived, it is clear that in this experiment the dried skim milk preheated at a temperature of $77^{\circ}$ for $15 \mathrm{sec}$ during processing was superior to the dried skim milk preheated at a slightly lower temperature but for a much longer period.

It is known from the early work of Fairbanks \& Mitchell (I935) with roller-dried skim-milk powder that the prolonged exposure to heat and the high intensity of the heat applied during the drying process have a marked lowering effect on the nutritive value of the proteins for the rat. It is thus probable that the poor performance of the calves given milk $\mathrm{A}$ was associated with denaturation of the whey proteins. The lactalbumin and lactoglobulin $\mathrm{N}$ in milk A comprised $6.3 \%$ of the total $\mathrm{N}$, which is in fairly close agreement with the figure of $5.5 \%$ obtained by Henry, Kon, Lea \& White $(\mathrm{I} 947-8)$ in a skim-milk powder dried by a similar process. There was probably no denaturation of the proteins in milk $\mathrm{B}$ which contained $13.3 \%$ of the total $\mathrm{N}$ as lactalbumin and lactoglobulin $\mathrm{N}$; this value is similar to the mean value of $12.5 \%$ for liquid milk found by Rowland (1938).

Our experiment is subject to the criticism that the two dried skim milks were not prepared from the same batch of liquid milk. However, it is extremely unlikely that there were any marked differences in the proximate composition of the two dried skim milks, since analysis of batches of the skim-milk powders used in later experiments showed very little difference in content of dry matter, lactose, ash, Ca and $P$.

The diet containing separated milk that had been subjected to UHT treatment gave results no better than the diet containing milk $\mathrm{A}$, but, as the performance of calves given the fresh separated-milk diet was unusually poor, there is insufficient evidence from this experiment, made under conditions of moderate to high 'infection' (see Roy et al. 1955; Ingram, Shillam, Hawkins \& Roy, 1958) to show that UHT treatment of a milk diet has a detrimental effect on the well-being of the young calf. However, in a more recent experiment, we have demonstrated a detrimental effect of UHT-treated whole milk when given to calves reared under conditions of low 'infection' (Shillam et al. 1960).

\section{SUMMARY}

I. Sixty-seven newborn calves were given $400 \mathrm{ml}$ separated colostrum and were used in an experiment, made under conditions of moderate to high 'infection', to compare the performance of calves that were given either a skim milk preheated before being spray-dried at a temperature of $74^{\circ}$ for about $30 \mathrm{~min}$ (milk A) or a skim milk given a less severe preheating treatment at $77^{\circ}$ for $15 \mathrm{sec}$ (milk B) or UHTtreated $\left(135^{\circ}\right.$ for $\mathrm{I}-3 \mathrm{sec}$ ) separated milk or fresh separated milk.

2. Although the differences were not statistically significant, mortality associated mainly with an $E$. coli localized intestinal infection was greater in calves given milk A, fresh separated milk or UHT-treated milk than in those given milk B. 
3. Live-weight gains of surviving calves given milk B were significantly greater than those of surviving calves on each of the other treatments.

4. None of the non-casein protein nitrogen in milk $\mathrm{B}$ appeared to have been denatured during the drying process, whereas the non-casein protein $\mathrm{N}$ in milk $\mathrm{A}$ amounted to only $56 \%$ of that in milk B.

5. The diet containing UHT-treated separated milk appeared to be as detrimental to the calf as the diet containing milk A. However, as the mortality rate of calves given the diet containing fresh separated milk was high and the growth rate of the surviving calves was low, no definite conclusions can be made from the results of this one experiment as to the effect of UHT treatment on the nutritive value of milk for the calf.

We are much indebted to Dr S. K. Kon for his helpful interest and to Dr R. Aschaffenburg for determining the nitrogen fractions of the milks.

\section{REFERENCES}

Aschaffenburg, R. \& Drewry, J. (1959). Int. Dairy Congr. xv. London, 3, 1631.

Fairbanks, B. W. \& Mitchell, H. H. (I935). F. agric. Res. 5I, I I07.

Henry, K. M., Kon, S. K., Lea, C. H. \& White, J. C. D. (I947-8). F. Dairy Res. 15, 292.

Ingram, P. L., Shillam, K. W. G., Hawkins, G. M. \& Roy, J. H. B. (1958). Brit. F. Nutr. 12, 203.

Rowland, S. J. (1938). F. Dairy Res. 9, 47.

Roy, J. H. B., Palmer, J., Shillam, K. W. G., Ingram, P. L. \& Wood, P. C. (1955). Brit. F. Nutr. 9, II.

Roy, J. H. B. \& Shillam, K. W. G. (1960). Rep. nat. Inst. Dairy. Reading, p. 45.

Shillam, K. W. G., Dawson, D. A. \& Roy, J. H. B. (1960). Brit. F. Nutr. I4, 403.

Shillam, K. W. G., Roy, J. H. B. \& Ingram, P. L. (1962). Brit. $\mathscr{F}$. Nutr. 16, 267. 